\title{
ArcheoSciences
}

Revue d'archéométrie

$31 \mid 2007$

Varia

\section{Archaeometrical analysis of mural paintings made by Spyros Papaloukas (1892-1957) in Amfissa cathedral}

Analyse archéométrique des peintures murales entreprises par Spyros

Papaloukas (1892-1957) dans la cathédrale d'Amphissa

Ioannis Liritzis and Eliza Polychroniadou

OpenEdition

Journals

Electronic version

URL: https://journals.openedition.org/archeosciences/803

DOI: 10.4000/archeosciences.803

ISBN: 978-2-7535-1596-3

ISSN: $2104-3728$

Publisher

Presses universitaires de Rennes

\section{Printed version}

Date of publication: 31 December 2007

Number of pages: $97-112$

ISBN: 978-2-7535-0618-3

ISSN: 1960-1360

Electronic reference

Ioannis Liritzis and Eliza Polychroniadou, "Archaeometrical analysis of mural paintings made by

Spyros Papaloukas (1892-1957) in Amfissa cathedral", ArcheoSciences [Online], 31 | 2007, Online since

31 December 2009, connection on 01 February 2022. URL: http://journals.openedition.org/

archeosciences/803; DOI: https://doi.org/10.4000/archeosciences.803 


\title{
Archaeometrical analysis of mural paintings made by Spyros Papaloukas (1892-1957) in Amfissa cathedral
}

\author{
Analyse archéométrique des peintures murales entreprises \\ par Spyros Papaloukas (1892-1957) dans la cathédrale d'Amphissa
}

\author{
Ioannis Liritzis* and Eliza Polychroniadou**
}

\begin{abstract}
Combined spectroscopy methods of analysis were applied to the contemporary mural paintings of the Amfissa Cathedral (Church of the Annunciation painted during 1926-32) in Fokida province, Central Greece, including EDXRF, FTIR, IR-PAS, RAMAN, XRD, gas chromatography and digital photography, with a twofold aim: a) identify paint media and artist's pigments and materials used during previous conservation treatments, and b) investigate Papaloukas' marked influence on his artistic development in relation to the artistic movements of the 20th century artists, an elaborated perfectionist whose creative abilities enabled him to explore the complex trends in modern painting and produce a series of works varied from impressionism to early expressionism. Identified pigments include ultramarine, charcoal, haematite, yellow ochre, Prussian blue, lead white, chrome yellow. Several painted layers were consisted of yellow ochre (goethite), calcite, used as white pigment, red ochre (anhydrous iron oxide), ultramarine. Pigments were mixed with binding mediums such as animal glue, casein or egg. Gas chromatography identified the presence of egg tempera and animal glue.

Résumé : Des méthodes combinées de spectrométrie EDXRF, FTIR, IR-PAS, RAMAN, XRD, chromatographie gazeuse et photographie digitale ont été appliquées aux peintures murales de la cathédrale d'Amphissa (Église de l'Annonciation, peinte entre 1926 et 1932) dans la province de Phocide, en Grèce Centrale. Cette recherche a un double but: a) identifier les techniques de peinture, les pigments de l'artiste et les matériaux utilisés durant les phases de traitement précédentes et b) comprendre l'influence marquée dans le développement artistique de Papaloukas - un perfectionniste dont les habiletés créatives lui ont permis d'explorer les tendances complexes dans la peinture contemporaine et de produire une série d'oeuvres variant de l'impressionisme à l'expressionisme - en relation avec les mouvements artistiques des artistes $d u X X X^{\prime}$ siècle de notre ère. Les pigments identifiés comprennent ultramarine, anthracite, hématite, ocre jaune, bleu de Prusse, blanc de plomb, jaune chrome. Plusieurs couches de peinture sont composées d'ocre jaune (goethite), calcite utilisée comme pigment blanc, ocre rouge (anydre oxyde de fer, ultramarine. Les pigments y ont été mélangés à des liants, comme la colle animale, la gouache ou l'auf. La chromatographie gazeuse a permis d'identifier la présence de tempera à l'ouf et de colle animale.
\end{abstract}

Key words: Amfissa Cathedral, Spectroscopy, IRPAS, FTIR, Raman, Optical, Pigments, Art, Anthivola, Conservation.

Mots clés : Cathédrale d'Amphissa, Spectrométrie, IRPAS, FTIR, Raman, Propriétés optiques, Pigments, Anthivola, Conservation.

\footnotetext{
* Laboratory of Archaeometry - University of the Aegean, Dept.of Mediterranean Studies, 1 Demokratias Ave., Rhodes85100, Greece(liritzis@rhodes. aegean.gr)

** Conservation and Restoration of Works of Art and Monuments, 13 Omirou str, Neo Psibiko, Athens 15451, Greece (eliza@ath.forthnet.gr)
}

rec. Ap. 2007 ; acc. Oct. 2007

ArCheoSCIEnces, revue d'archéométrie, 31, 2007, p. 97-112 


\section{INTRODUCTION}

Among the artists who largely contributed to the development of contemporary Greek art, Spyros Paploukas, is undoubtedly a significant figure (Spiteris, 1982; LambrakiPlaka, 2006). During his studies in Paris he became acquainted with the artistic movements of the $20^{\text {th }}$ century which had a significant influence in his artistic development. Throughout his career, Papaloukas ranged over the boundaries of painting, in a constant search of new themes and incentive, an elaborated perfectionist whose creative abilities and esoteric quality enabled him to explore the complex trends in modern painting and produce a series of works varied from impressionism to early expressionism. He uses colour not as a merely descriptive adjunct to form, but as the most potent means of expression and the dominant element of his compositions. Between 1926-1932 he undertook a major artistic venture, the painting of the interior murals of the Amfissa Cathedral (Church of the Annunciation) a cross-domed church built in 1868 on the ruins of an early Christian basilica. In this 1000 sq monumental work, Papaloukas, even though he follows the strictly established rules of Byzantine ecclesiastical art, he dares to attempt a revolutionary approach to the aesthetic merits of Byzantine iconography by introducing elements of the postImpressionists ${ }^{1}$, the Fauvists ${ }^{2}$ and the $\mathrm{Nabis}^{3}$ (Reed, 1966; Binder, 1997) (Fig. 1). In the mural paintings of the Amfissa Cathedral his main concern was the visual effect of his paint giving less value to the technical process. To achieve this he combined non-homogeneous materials and techniques.

The mural paintings were in poor conservation condition with extensive loss of paint and overall flaking. Defective conservation treatments and various interventions between 1970-1994 contributed immensely to the loss of a major part of the original painting. Immediate rescue conservation interventions had to take place based on scientific methods

1. Artistic movement in France (1880-1900) an extension of impressionism. The term Post-Impressionism is applied to the work of late 19thcentury painters as Paul Cézanne, Georges Seurat, Paul Gauguen, Vincent van Gogh, Henri de Toulouse-Lautrec, and others

2. A small group of artists, the wild beast as they were called, who, shortly after the turn of the century, exploded onto the scene with a wild, vibrant style of expressionistic art. Fauvism (1898-1908) grew out of Pointillism and general Post-Impressionism, but is characterized by a more primitive and less naturalistic style. Paul Gauguin's style and his use of colour were especially strong influences. Fauvism was the path to both cubism and modern expressionism.

3. Les Nabis (1891-1899) were a Parisian group of Post-Impressionist artists and illustrators who became very influential in the field of graphic art. Their emphasis on design was shared by the parallel Art Nouveau movement. Both groups also had close ties to the Symbolists. The core of Les Nabis was Pierre Bonnard, Maurice Denis, Ker Xavier Roussel, Felix Vallotton, and Edouard Vuillard.

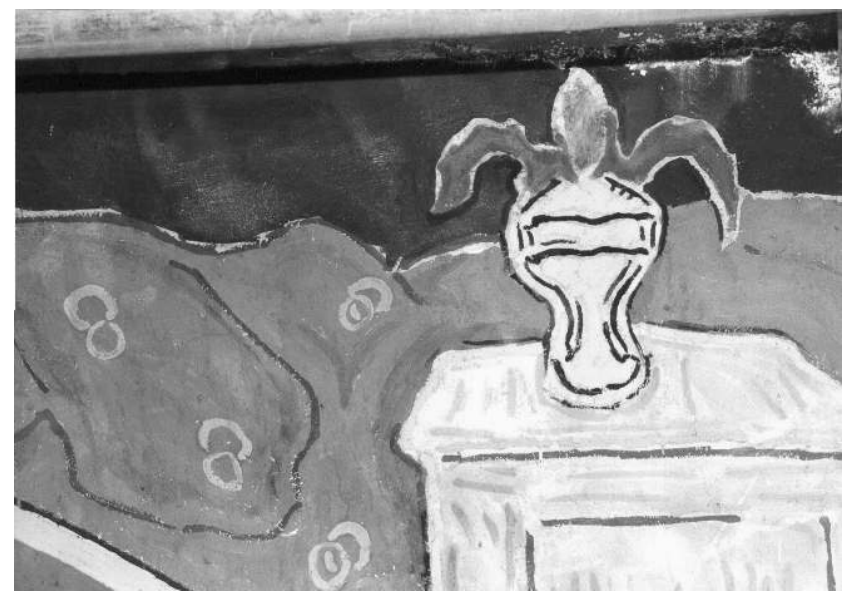

Figure 1: The Amfissa Cathedral: Upper north wall, right aisle. Detail of ornamental composition influenced by Matisse. Size: $46 \times 49 \mathrm{~cm}$.

Figure 1: Cathédrale d'Amfissa. Mur nord supérieur, aile droite. Détail de la composition ornementale influencée par Matisse. Dimensions $46 \times 49 \mathrm{~cm}$.

of analysis, that would help guide decisions about care and conservation treatment.

Our present work refers to the so far obtained results from archaeometrical techniques applied to minute samples and on a non-destructive manner and testing applied directly on the mural paintings in order to identify pigments, binders and substrate matter, a pre-requisite step to any further conservation work (Cotte et al., 2007; Schwan, 1998; Baumann et al., 1998; Mora et al., 1984).

\section{Modern SCIENCE AND CONTEMPORARY MURAL PAINTINGS}

Amongst the frequently used methods in wall painting, pigments, lacquers and media, are, Polarizing Light Microscopy (PLM), Scanning Electron Microscopy (SEM) and SEM-EDS, X-ray fluorescence (XRF), X-ray diffraction (XRD), Binocular Microscopy, Fourier Transform Infrared Spectroscopy (FTIR), Gas-ChromatographyMass Spectrometry (GC-MS), High Performance Liquid Chromatography (HPLC), Inductively Coupled PlasmaOptical Emission Spectroscopy (ICP-OES), ultraviolet/ visible absorption spectroscopy (UVS), visible absorption spectroscopy (VS), Raman Spectroscopy (Welcomme et al., 2007; Kakouli, 2002; Laurie, 1910 a, b; Mills and White, 1994, 1977; Lucas and Harris, 1962; Lorusso and Schipa, 2001; Ferretti, 1993). 
In particular XRF, XRD and mineralogical microscopic examinations of wall paintings have been reported (e.g. Leona and Winter, 2001; Fillipakis et al., 1976, 1979; Cameron et al., 1977, Calamiotou et al., 1983).

Projects concerning characterization of wall paintings range from prehistoric right through Classical, Hellenistic to Roman, Medieval and contemporary and modern times (e.g. Lucas and Harris, 1962; Mantler \& Schriner, 2001; Wallert, 1995; Leona and Winter, 2001).

Early works and historical reports, such as Lucas on Egyptian materials, Church and Laurie and Cennini on artists' techniques, the $19^{\text {th }}$ century explications of early manuscripts and printed works by Merrifield and by Eastlake, as well as, original sources themselves, such as, Theophilus and Pliny; all these are valuable guides as to what organic materials might be expected to be found in museum objects and mural paintings (Lucas and Harris, 1962; Church, 1915; Merrifield, 1849; Eastlake, 1967; Hawthorne and Smith, 1963; Cennini in $14^{\text {th }} \mathrm{c}$ translated in 1933; Pliny).

During the whole of the 20th century, it has been a usual practice that the artists continually redefined the conception of what constitutes art, a process that included a proliferation in the employment of materials not previously known or used. Since never before in history, artists have had at their disposal a tremendous assortment of natural and synthetic material, and moreover the license to use them. This profusion of products has been wholeheartedly embraced by modern artists. Art now incorporates new materials that include pigments with unprecedented variety, plus a plethora of synthetic paint media, exquisitely transparent plastics, fabrics, exotic metal alloys, quick-setting adhesives, and electronic devices, to name merely a few.

Moreover, the long-established field of painting has seen a change. For example, paintings created in earlier eras reflected a relatively limited supply of artists' materials, therefore the only available paint media were waxes, plant gums, egg, milk, animal hides, vegetable oils, and plant resins. Pigments came from mineral deposits properly processed (see Theophilus' and Pliny's treatise on this) or were extracted from plants, insects, and animals. Today, however, artists are not limited to these traditional materials and processing techniques but may also choose from a variety of commercial paint media, as well as a profusion of new synthetic pigments.

Taken for granted that research into artists' materials and their use plays an important role in conservation projects, the tremendous increase in the number of available materials has created new challenges for conservation professionals (Grattan, 1993).
The yielded information, from the examination and analysis of artists' paints, about artistic techniques and materials helps the taking of decisions about care and conservation treatment. Therefore, conservators of modern art also take a keen interest in art as a process, carefully researching the ideas behind the specific techniques that the artist used to create the work. The challenge is finding conservation solutions that preserve a painting without disregarding the artist's intent.

Nevertheless, even with these resources, much work remains to be done in identifying the vast number of materials used by contemporary and modern artists and in developing a better understanding of the properties of these materials. Archaeometry and Conservation science can play a significant role in this effort. There are now a number of scientific analytical techniques, such as those abovementioned, to aid and identify artists' materials and techniques - and although most were refined and developed to study works of art made with more traditional materials, they can also be applied to 20th century artworks and their materials.

Identification of the materials - and their properties - in contemporary objects and new developments is being pursued at several major institutions. Thomas Learner, Tate Gallery, London, developed a technique to identify modern paint media using pyrolysis gas chromatography- mass spectrometry. Paul Whitmore, Carnegie Mellon Research Institute, developed a device for assessing, in a microscopicsized spot, the lightfastness of contemporary colorants early in an object's life. Scientists at the Canadian Conservation Institute constructed a transportable FTIR spectrometer that has been used to differentiate traditional materials such as Japanese lacquer from imitations made from cashew oil or alkyds.

The application of scientific analytical techniques to contemporary works of art has increased understanding of artists' materials and techniques (pigments, binding media, natural ageing materials). Polarized light microscopy, XRF, XRD, GC, LC, MS, FTIR were applied to the paintings of the 20th-century U.S. artists - Willem de Kooning and Jacob Lawrence - conducted in the laboratories of the Getty Conservation Institute and the National Gallery of Art (Schilling et al., 2002). This research illustrated how modern science can reveal new insights about contemporary works of art, which ultimately can aid in the conservation of these works (Doehne et al., 1989; Bower et al., 1994)

An integrated collaborative project initiated in 2002 by Tate, London, the National Gallery of Art (NGA), Washington, D.C., and the Getty Conservation Institute (GCI) gave answers to some of the many questions regarding the cha- 
racter of modern paint materials, focusing on the cleaning of modern paintings, chemical analysis, and physical characterization (Learner et al., 2002. In 2000, 11 European museums, coordinated by the ICN and Tate Modern, established the International Network for the Conservation of Contemporary Art (INCAA) (see, www.incca.org).

\section{HistoricAl AND ARCHITECTURAL CONTEXT}

In order to appreciate the impact of Papaloukas on Greek early $20^{\text {th }}$ century painting movement, some basic factual elements on major artistic movements, for the non-specialist, are necessary. He was born in 1892 at Desfina, a village close to the archaeological site of Delphi. The environmental landscape and the archaeological site of Delphi were the first impressions and later inspirations depicted in a large part of his works including the decorative and figurative painting on the interior walls and ceiling of the Amfissa Cathedral.

In Greece, Byzantine art was adhered to rigid rules. It was a Christian art dedicated to the service of the Church controlled at a major part by the Church. In that concept any attempt for evolution and renovation was not acceptable. Papaloukas' revolutionary approach, although appreciated at an early stage by the local community, it was ended up as a hostile attitude against him, egged by the clergy.

\section{Original Techniques Used By Papaloukas}

This section contains visual and macroscopic observations made in situ by E. Polychroniadou, in conjunction with data available from the present analysis. The paintings were carried out on a single layer of lime mortar applied directly onto the wall, that is, a secco. The pigments were applied to the dry ground mixed with lime or casein, egg, animal glue, linseed oil or vegetable gum. The artist renders the contour of the figures by an arbitrary thick line which has a vital quality and applies rich amount of pigments on particular areas of his compositions to achieve distinctive visual effects.

Papaloukas prepared over 320 pre-drawings (anthivolo-a as it is the equivalent in Greek $)^{4}$ for his perspective compositions (Figs 1, 4) in the Amfissa Cathedral.

4. The mural paintings were executed from a preparatory drawing on paper - anthivolo, in Greek - of exceptional artistic quality. The initial compositions were drawn by pencil or charcoal and transferred to the wall. The use of prickled cartoons and in fact is an ancient technique for transfer of designs. There are 340 anthivola of the Amfissa Cathedral, which form a unique collection of preparatory religious drawings.
The anthivolo (Fig. 2) was applied for the illustration of the Archangel on the sofa of the narrow upper arch at the right aisle.

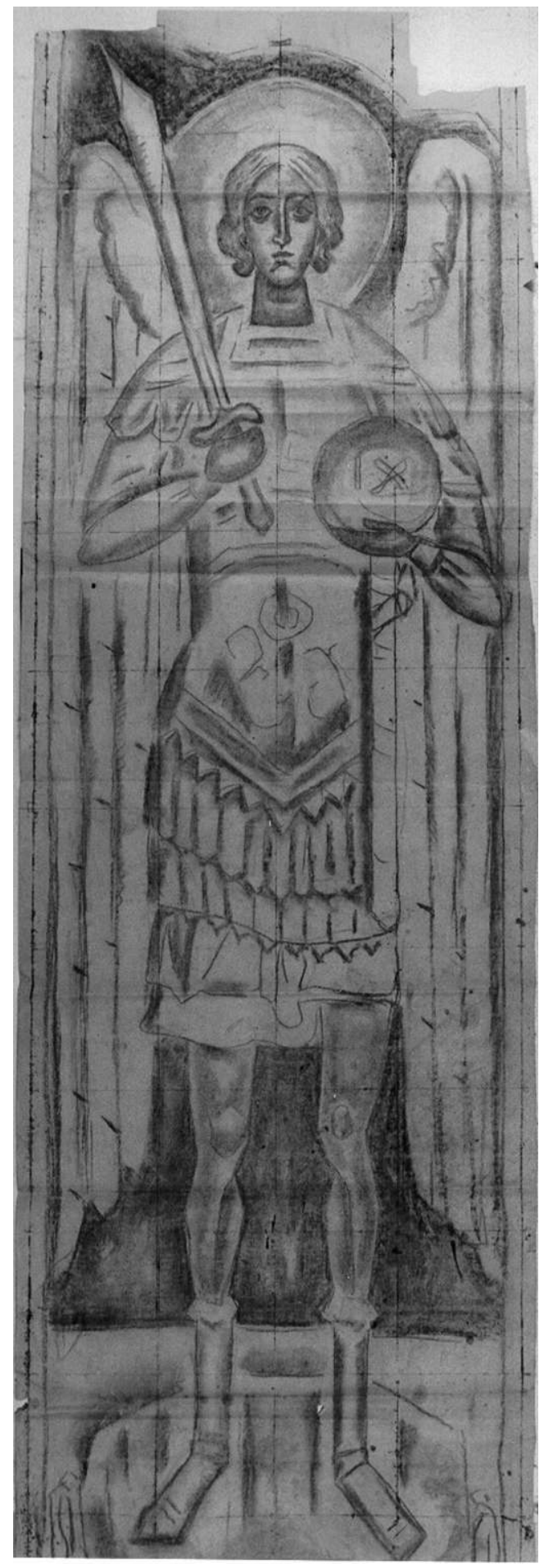

Figure 2: Anthivolo: The Archangel (Municipality of Amfissa collection). Size: 3.30 x $0.85 \mathrm{~cm}$.

Figure 2 : Anthivolo: l'Archange (collection de la municipalité d'Amfissa). Dimensions : 3,30 0,85 cm. 
He transferred the pre- drawings on the wall by piercing a series of small holes with a pointed instrument, actually the one used at the time by dress makers, so that the drawing would be reproduced by dabbing it on the back side with a gauze sachet filled with charcoal powder.

The anthivola, property of Spyros Papaloukas's daughter, stand on their own as works of art, evidence of his creative thought processes and his technical virtuosity as a painter. Mrs Mina Papalouka offered them to the Amfissa Municipality as the main subject of the Spyros Papaloukas Gallery in Amfissa.

\section{Current Condition AND PREVIOUS INTERVENTIONS}

The serious defects in the initial structure of the building, the low quality of materials provided by local shops, the experimental techniques the artist applied to achieve distinctive visual effects, the input of rain water from the roof, and defective conservation treatments and various interventions between 1970-1994 contributed immensely to the loss of a major part of the original painting noticeably worse in areas at the ceiling of the dome, the apses and the ceiling of the gynaeceum (the apartment reserved for women at the upper level of the church) at the right and left nave (Fig. 3). The paint layer was in an unstable and deteriorated condition,

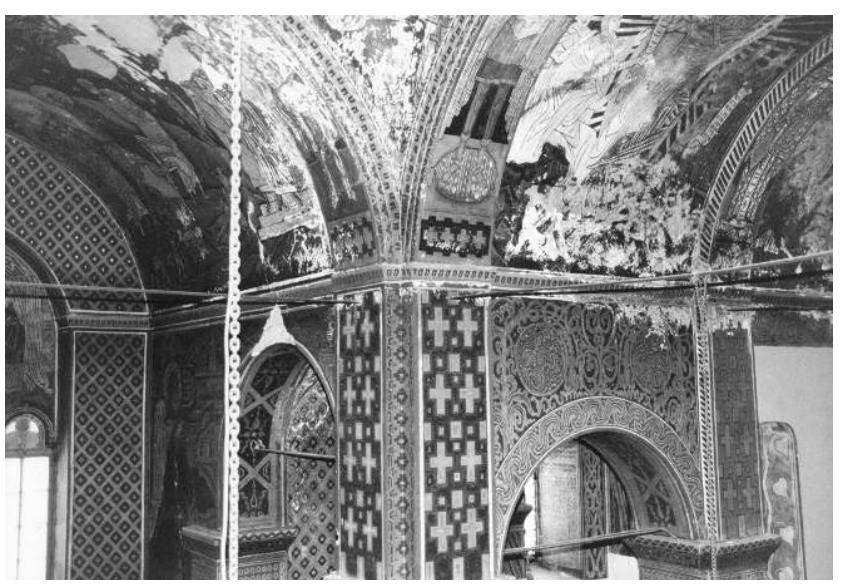

Figure 3: The gynaeceum (women gallery) at the left aisle. Major losses of painting observed on the ceiling. Pigments and substrates from point locations of this part and similar ones from other parts of the church were sampled and processed in the lab or analyzed in situ.

Figure 3: Le Gynécée (galerie des femmes) dans l'aile gauche. Principales pertes de peinture observées sur le plafond. Des pigments et substrats provenant de points localisés de cette partie et de points similaires d'autre parties de l'église ont été échantillonnés et traités au laboratoire ou analysés in situ. many areas were insecurely attached, flaking and extremely friable and they tented to shatter even when slightly touched.

Furthermore, the seismic activity of the region was the main cause for the move of structural materials resulted as exhibit of numerous cracks and deterioration of mortar joints

The conservation treatments and several interventions occurred during 1970-1994 were aimed at the stabilization of the structural elements of the building and the mural paintings. There was extensive use of cement for the reinforcement of structural elements, joints of vertical walls and replacement of wooden structures such as the wooden staircase at the left side of the nave leading to the upper floor. Cement was also used as an ingredient of the mortar to fill the losses of the paint. Besides, structural work on the roof of the Cathedral required partial removal of the tiled roof and replacement with new tiles with cement rendering (Fig. 3). Loss or weakening of cohesion of the paint layer and flaking were mainly treated with Primal AC-33, Polyvinyl Acetate Emulsions and Casein in cases, since the latter has not yet fully located. But such a treatment concerns the next stage of the project which is beyond our prime scope of the present work (Baumann et al., 1998).

\section{The CONSERVATION PROJECT}

Lengthy discussions and the obvious need for restoration of the Amfissa Cathedral interior mural paintings led to the appointment of a conservation team and conservation scientists to undertake the preliminary study before the actual conservation procedure. The conservation project started on May 2001 under the auspices of the mayor of Amfissa, the daughter of the artist and the general director, General Directorate of Cultural Development, Hellenic Ministry of Culture.

\section{SAMPLiNG}

Sampling locations ranged from the ceiling to ground level and on various decorative motifs and compositions. Only minute samples (millimeter scale) were permitted to obtain. Any perceptible invasive sampling was avoided. Non-destructive EDXRF measurements were performed on hagiographic representations in the pulpit, the women's gallery, and the left aisle. In all 26 samples (minute sampling) were analysed and 114 measurements (minute sampling \& 10 non-destructively) with all methods were made; 64 
Raman, 14 FTIR, 27 EDXRF (10 on the painting), 7 GCMS and 2 IRPAS.

\section{Methodology}

The following techniques were applied: FTIR (Fourier Transform Infrared), IR-PAS (Infrared Photoacoustic Spectroscopy), RAMAN, EDXRF (Energy Dispersive Xray Fluorescence), optical microscopy (in the visible and UV regions) and GC-MS (Gas Chromatography by Mass Spectrometry) were combined, as an integral part of the present archaeometrical examination ${ }^{5}$ (e.g. Kakouli, 2002) (Tables 1-4).

\section{XRF (X-Ray Flourescence)}

In situ XRF measurements, as well as some laboratory measurements, were performed for a semi-quantitative recognition of pigments, from major and minor element presence. The EDXRF field portable analyzer Spectrace 9000 TN was used with a mercuric iodide $\left(\mathrm{HgI}_{2}\right)$ detector, which has a spectral resolution of about $260 \mathrm{eV} \mathrm{FWHM}$ at 5.9 $\mathrm{keV}$, and three excitation sources of radioisotopes within the probe unit - Americium Am-241 (26.4 KeV K-line and 59.6 KeV L-lineV) measuring Ag, Cd, Sn, Ba, Sb; Cadmium Cd-109 (22.1 K-line, 87.9 K- \& L-line KeV) measuring Cr, $\mathrm{Mn}, \mathrm{Fe}, \mathrm{Co}, \mathrm{Ni}, \mathrm{Cu}, \mathrm{Zn}, \mathrm{As}$, Se, Sr, Zr, Mo, Hg, Pb, Rb, Th, $\mathrm{U}$; and Iron Fe-55 (5.9 KeV K-line) measuring K, Ca, Ti, $\mathrm{Cr}$. The wide range of excitation $\mathrm{x}$-ray energies theoretically can measure all chemical elements from sulfur to uranium. However, limitation factors produce a lower threshold of detection, and in practice 26 simultaneous elements in soil are measured, in surfaces up to a depth of a few millimeters (thickness depends on the atomic number of the element measured and sample density). The minimum detection limits of measured elements were bound by three criteria, as defined by EPA, a) three times the standard deviation taken from a blank sample, b) a statistically significant number of measurements are taken to determine the actual standard deviation which is then multiplied by three, and c) the

5. Figures 4, 5B, 6, 8 and respective measurements in Tables 1-4 with Raman, FTIR, GC and digital photos, were executed at the Ormylia Diagnostic Centre of Art Objects, Athos, Greece, on service, (c/o Dr C. Andrikopoulos and Dr Tsakalof); Fig. 7B and Raman measurements in Tables $1-3$ by Travis Thompson, DeltaNu (USA); Fig.9 and FTIR/ IRPAS measurements of Table 3 by Dr Chris Stevenson at Virginia, Dept. of Historical Resources, USA; and a few XRDs by our collaborator Prof. V. Perdikatsis, Technical University of Crete. Microscopic examination by PLM and digital photos were taken on more samples in the Laboratory of Archaeometry, University of the Aegean, Rhodes, Greece. minimum detection limit will decrease as measurement time increases ( $4 \mathrm{x}$ counting time approx. $=1 / 2$ detection limit). Prior to any course of measurements reliability tests were applied to reassure the instrumental stability of the analyzer (gain and energy drifts, calibration of energy axis), though the instrument had an automatic gain compensation). The instrument is powdered by rechargeable batteries which have a field endurance of $4-5 \mathrm{~h}$. Small artifacts are analyzed by placing them over the $25 \mathrm{~mm}$ diameter analyzer window. When an analysis sequence is initiated, each source is exposed automatically in turn behind the analyzer window to excite the $25 \mathrm{~mm}$ diameter area on the surface of the sample. Count times for individual radioisotope sources may be optimized according to the application, but total count times selected for this work were less than $10 \mathrm{~min}$. At the end of each analysis sequence, spectra from each source are deconvoluted by the data processing software to determine fluorescence intensities for a pre-selected range of elements. These intensity data are then quantified automatically using a fundamental parameter correction procedure, incorporating sample matrix corrections, based on factors that are preprogrammed for the appropriate application (in this case, silicate rocks). Results were viewed on the integral display screen and are stored for subsequent down-loading to a PC and printer through an RS232 port. The performance of the portable XRF instrumentation in the laboratory has already been reported (Liritzis, 2007; Mantzourani \& Liritzis, 2006), while the entire concept of the present investigation may be applied to any available portable XRF instrument that requires an irradiated area than a point focus. Here, a wide range of silicate rock reference materials were analyzed as powder pellets to evaluate accuracy, precision and detection limits. Reference samples included (rhyolites, metals, clays, soils, low radioactivity reference samples). The study showed the capability of the instrument to determine major and minor elements $(\mathrm{K}, \mathrm{Fe}, \mathrm{Ca}, \mathrm{Mn}, \mathrm{Ti})$ and selected trace elements ( $\mathrm{Sr}, \mathrm{Zr}, \mathrm{Ba}, \mathrm{Rb}, \mathrm{Pb}, \mathrm{Mo}$ ) in typical silicate (rhyolitic) rocks. Other trace elements were not measured because their lower counting sensitivities mean that the concentrations were near to or below detection limits. Samples measured in the laboratory were dried overnight to oven at $75^{\circ} \mathrm{C}$ prior to any measurement.

This non-destructive technique was used as sampling was restricted in view of the value and the condition of the wall paintings. Particularly in the scene of the Nativity on the right barrel-vaulted arm of the cross, and on the anthivola preparatory drawings papers (see, footnote 4).

However, limitations due to $\mathrm{x}$-ray attenuation by absorption make the technique ideal for smooth surface analysis. Care is taken to avoid any surface secondary products from 
weathering / erosion effects, while for very thin layers, such as the painted layers, the obtained data provide semi-quantitative results, while in cases of multi-layered compositions, the recorded spectra are composite from all layers without separation. It was also applied on some minute samples from small loose fragments or deteriorated areas on the wall, but mainly on the actual paintings by placing the probe in contact with the point of interest, in a non-destructive manner (The present XRF has been applied extensively in archaeological materials, e.g. Liritzis et al., 2002; Mantzourani and Liritzis, 2006; Papageorgiou and Liritzis, 2007; Liritzis, 2007, and in mural paintings, e.g. Agnoli et al., 2007; Capitan-Vallvey et al., 1994). Therefore, the present analysis represents an area on the mural painting covered by the diameter of the counting window of around $25 \mathrm{~mm}$ and in a variable depth of some millimeters which accounts for any more elements detected, beyond those representing the pigment minerals. Simulation experiments and numerical calculations have shown this result (Liritzis, 2007).

\section{FTIR (Fast Fourier Infrared Transform)}

FTIR (Low and Baer, 1977) and a first use of Infrared Photoacoustic Spectroscopy (IR-PAS) were used to define any organics (lacquers such as binders, varnishes), and inorganic pigments. The tiny sample becomes a thin section less than $1 \mathrm{~mm}$ thick or for crystals they become compressed or in powder form $1 \%$ diluted in $\mathrm{KBr}$ for disc preparation, and the IR beam passes through. Here, samples were mounted on resin, cut with diamond saw and grinded by means of successively finer grades of abrasive. This way fine superimposed painted layers (micro-stratigraphy) were possible to be seen from CCD digital images in the microscope under visible or UV light (see, $\mathrm{d}$ below). FTIR sample sizes 50-100 $\mu \mathrm{m}$ in thickness were cut, compressed in a diamond compressed cell and spectra were obtained. The FTIR used was that of Biorad (FTS-45A coupled with microscope UMA500). In several cases IR is used to identify water in natural glasses, gypsum or ambers. Hydration is used in ageing experiments and may aid authenticity of some objects and pigments and even their dating (Stevenson et al., 2002; Goodall et al., 2004; Low and Baer, 1977).

\section{IR-PAS (Photoacoustic Infrared Spectroscopy)}

The determination of the binders and pigment concentration level within a painted layer can also be obtained with an infrared photoacoustic accessory. In this technique, a sample less than $10 \mathrm{~mm}$ in diameter is placed in a helium-filled chamber equipped with a high sensitivity microphone. The specimen absorbs the infrared radiation and undergoes an oscillatory heating and becomes a source of thermal waves. The waves within the bulk sample propagate to the surface and into the helium atmosphere. The photoacoustic signal is generated at the surface and is caused by the thermal expansion of the gas (McClelland et al., 1993; Newman et al., 1986).

The magnitude of the signal varies in proportion to the concentration of the searched species. The absorbance values are calculated from integrated peak areas. Each absorbance value represents an averaged measure for the entire surface of the sample exposed to the $5 \mathrm{~mm}$ diameter infrared beam.

IR-PAS used to measure the concentration of various species in the painted surface layer is a MTEC 300 photoacoustic cell accessory for a Bomem MB-120 spectrometer. Each sample will be run at a resolution of 8 wave numbers for 256 scans. Carbon black, supplied by the manufacturer, is used to establish the background conditions for the instrument. Several absorption spectra were obtained on standard pigments which served as a data bank, and the identification of pigments and binding media of an unknown composite spectrum was achieved with appropriate spectrum standardization and multivariate analysis (Liritzis et al., 2008a) (Fig. 9). The results of analysed samples are referred to Tables 3, 4.

Here, the IR and XRF techniques were used to recognize a) pigments, b) lacquers, c) oils or resins (Gettens and Stout, 1966; Doerner, 1984; White, 1981).

\section{GC-MS (Gas Chromatography with Mass Spectrometry)}

A Finnigan Gas Chromatography with Mass Spectrometry (GC-MS) was used for identification of the organics present (aminoacids etc), following standard procedures (White, 1978; Kitson et al., 1996)

\section{Raman}

Raman spectroscopy for the recognition of particular colors attributable to certain pigments chemical compounds through comparison with available data bank spectra (special data base software for arts developed on an $\mathrm{d}$ base compiler) (e.g. Clark, 2007). Equipments used are: a) 1000 $\mu$ Raman, Renishaw, with a He-Ne laser light source (632.8 $\mathrm{nm}$ ), and use of $\mathrm{x} 50$ and $\mathrm{x} 100$ objective lenses of Olympus, the focusing of around $1 \mathrm{~mW}$ power laser beam was made on single spots of a cross-sectioned sample, and on the surface, with a spectral resolution of $4 \mathrm{~cm}^{-1}$, b) ExamineR High Performance Microscope System DeltaNu, 785 nm laser 
beam, BX51 Olympus camera, resolution $\sim 4 \mathrm{~cm}^{-1}$, diameter spot size $\sim 1 \mu \mathrm{m}$, and c) the RockHound Raman System of DeltaNu with Nuscope, $785 \mathrm{~nm}$ laser beam FSX technology, resolution $-8 \mathrm{~cm}^{-1}$ and diameter spot size $-35 \mu \mathrm{m}$ (Liritzis et al., 2007; Guineau, 1989; Coupry and Lautie, 2001). In some samples with contaminated surface the raman spectra were mainly from fluorescence. In these cases laser beam persisted to remove this secondary product and reduce significantly fluorescence, and measure the raman spectrum of the actual underlying painted layer. All Raman spectra are baseline corrected for a better visualization of the results. Three types of Raman instruments were used. In the first instance (a) was used for an initial phase of the project, and (b, c) were applied in a later phase of the project pinpointing on certain mineral spots of same and newer samples, and for investigating the efficiency of the portable RockHound for in situ collection of spectra in a non destructive manner.

\section{Imaging}

Photographic recording is a pre-requisite step prior to any further analysis. Photos of sample surface and sides to identify micro-stratigraphy were made using optical microscope stimulated by white polarized light and UV (Hg source), with objective lenses of $\times 10, \times 20$ and $\times 50$. The photos were obtained via a 3CCD camera (Gowing, 1999). The UV aids in some cases location of organic compounds from their fluorescent emission, as well as other binding media compounds with strong fluorescence (e.g. varnishes, lacquers, etc). By this way any painted layers as well as other carriers were identified, for further detailed microanalysis.

\section{Ray Diffraction (XRD)}

The XRD Powder Diffractometer was a Siemens D500, $\mathrm{Cu}$-Tube, Graphite Monochromator, 2-theta range 4-70 grad, step 0.02 grad, Time/Step $3 \mathrm{sec}$.

The mineral recognition was made by software DiffracPlus, Firma Bruker and the PDF-data Base (Powder Diffraction File).

More analytical work on X-ray diffraction for mineral identification of plaster or substrate and Scanning Electron Microprobe analysis for point chemical analysis and observation of multi-layered paints is under study (Liritzis et al., 2008b).

\section{Results}

The results as presented in Tables 1-4 are outlined below.

1) The painter used a wide 'paletta'. Amongst the various pigments are: ultramarine, $\left.\left(\mathrm{Na}_{8-10} \mathrm{Al}_{6} \mathrm{Si}_{6} \mathrm{O}_{24}\right) \mathrm{S}_{2-4}\right)$, carbon black, hematite or red ochre $\left(\mathrm{Fe}_{2} \mathrm{O}_{3}\right)$, yellow ochre $\left(\mathrm{Fe}_{2} \mathrm{O}_{3}{ }^{*} \mathrm{nH}_{2} \mathrm{O}\right)$ (though the principal matter is goethite, alpha-FeOOH) but kaolinite too, Prussian blue $\left(\mathrm{Fe}_{4}\left(\mathrm{Fe}(\mathrm{CN})_{6}\right){ }_{3}\right)$, lead white $\left(\mathrm{PbCO}_{3}{ }^{*} \mathrm{~Pb}(\mathrm{OH})_{2}\right)$, used from ancient times till today, lead chromate sulfate (member of the generic name chrome yellow) $\left(2 \mathrm{PbSO}_{4}{ }^{*} \mathrm{PbCrO}_{4}\right) . \mathrm{He}$ also used barium carbonate as white but also to dilute darker pigments. In one case of mortar the orange spot was identified by Raman as a type of fluorite $\left(\mathrm{CaF}_{2}\right)$ which is known to have an extreme variability in colors.

2) Stains of similar pigments were found in the anthivolon (Table 1, Fig. 4). In particular, various areas were analyzed by EDXRF and Raman - the paper support, red and black stains. The black stain contains mostly iron probably an unknown red paint poured accidentally on the tamping (tampon) layer of the prickled paper which contained sienna, chrome yellow, white of titanium, and others. The red stain contains much more iron identified as iron oxide (sienna). The rest of the paper contains faint yellow, traces of sienna, chrome yellow and lead oxide (orthorhombic massicot).

In particular, two pieces were analyzed (AMF-A1 of $26 \times 56.5-59 \mathrm{~cm}$, and AMF-A2 of $18 \times 85 \mathrm{~cm}$ ). Color was obviously dropped from the artist's brush while painting on the murals (Fig. 4). Anthivolo reference numbers AMF-A1 and AMF-A2 form part of linear design of a decorative motive. In AMFA2 several oily stains were observed. Portable EDXRF probe was focused on particular stains on their surface. For Raman spectroscopy also non-destructive analyses were performed scanning the surface and focusing laser beam $\mathrm{HeNe}$ $(632.8 \mathrm{~nm})$ on visually identified pigment mineral grains. Paper sample sizes 50-100 $\mu \mathrm{m}$ were cut, compressed in a diamond compressed cell and FTIR spectra were obtained. Paper and an oily stain were also confirmed with $\mu$ FTIR.

3) Samples AMF29 $9^{6}$, AMF13 (Fig. 6 and Table 2), AMF2 in Fig. 5 consist of five paint layers, yellow ochre (goethite), calcium carbonate for white, red ochre (anhydrous iron oxide), carbon black and ultramarine.

4) In AMF13 (mortar bearing painted layer, Fig. 6, 7, 9 ), the following pigments were recognized through IRPAS, FTIR, Raman techniques: a) yellow ochre (possibly goethite) b) calcium carbonate for the white, c) red ochre d) black of carbon, e) ultramarine, f) Prussian blue and g) fluorite $\left(-1880 \mathrm{~cm}^{-1}\right)$. Raman measurements were repeated by two different instruments, and an example is shown for Fig. 7, whereas the identification is based on the peaks found between 230 and $660 \mathrm{~cm}^{-1}$. Nevertheless, for other spectra the spectral region to $2000 \mathrm{~cm}^{-1}$ was also employed.

5) For AMF29 the successive layers B, C, D contain mainly ultramarine and Prussian blue. They are recognized

6. AMF 17 : AMFISSA + numbering of sampling. 

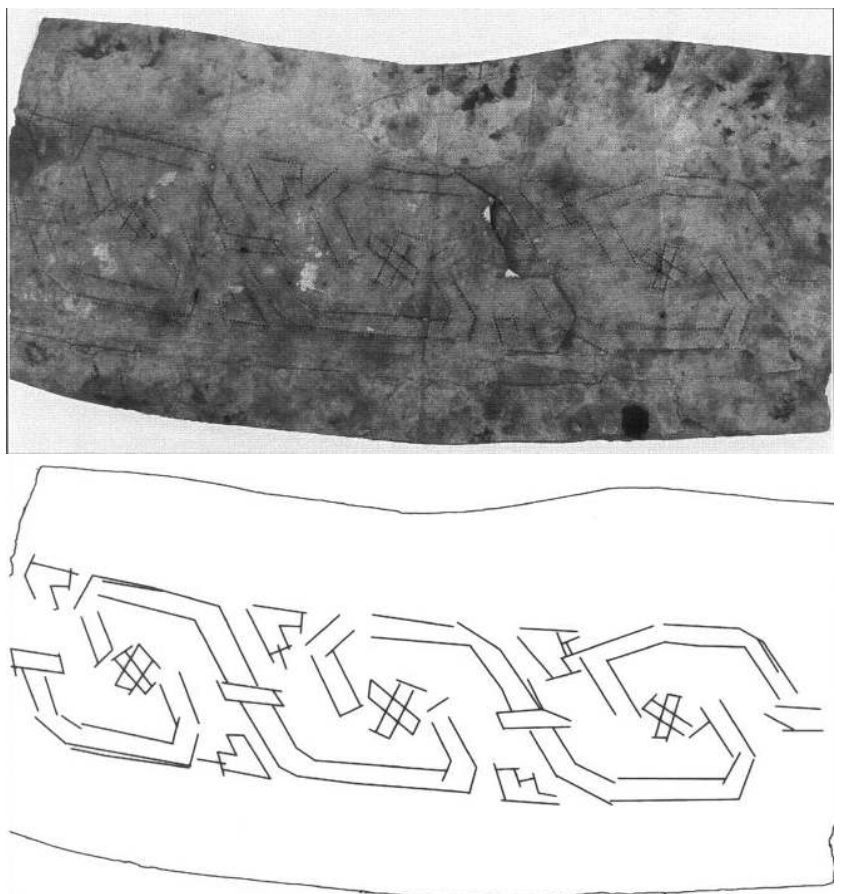

Figure 4: AMFA1 Digital photo of anthivolo (preparatory drawing on paper), used for the floral geometric motif illustrations on the apses of the women galleries at the upper parts of the right and left aisles in the visible spectrum, and a linear drawing sketch below $(26 \times 56.5-59 \mathrm{~cm})$.

Figure 4: Photo numérique d'anthivolo (dessin préparatoire sur papier), utilisé pour les illustrations du motif géométrique floral dans les absides des galeries des femmes dans les parties supérieures des ailes droites et gauches, dans le spectre visible, et ci-dessous un dessin schématique au trait $(26 \times 56,5 \times 59 \mathrm{~cm})$.

as distinct due to different contents of these two pigments. In layer $\mathrm{E}$ there exists strong mixing of red and blue pigment, but no Prussian blue has been used. The presence of organic substance in green is detected but could not be identified as one of the known pigments. Perhaps it derives from later interventions on the artwork. Similarly the dark pigment in layer A could not be identified.

6) In AMF17 $(\Gamma \Delta 3)^{7}$ of red from the ceiling, pigment and substrate, gypsum was recognized for white, Ultramarine for blue, red ochre together with a lacquer. This was found from magnifying photos of sample's profile in cross-sectioned form, in white and UV light coupled with Raman spectrum. The preparatory layer as well as the only red layer was seen.

7) Further X-Ray Diffraction was used in a few cases of tiny sample. The spectra have shown Gypsum substratum

7. $\Gamma \Delta 3: \Gamma$ for women gallery ( gynaeseum) $\Delta$ for Right aisle, 3 for 3rd apse.
$\left(\mathrm{CaSO}_{4}^{*} 2 \mathrm{H}_{2} \mathrm{O}\right)$ with quartz (AMF27), while in another case (AMF28) a variety of colored grains of blue, brown and white were located. The blue ones were due to lapis lazuli (sodalith, $\mathrm{NaS}\left(\mathrm{AlSiO}_{4}\right)_{6}\left(\mathrm{ClO}_{4}\right)_{2}$ ), the brown ones were due to hematite diluted with barite (Liritzis et al., 2008b).

8) The cross section of AMF2 have shown two painted layers. Fig. 5 (AMF2) show typical Raman spectrum respectively, and Table 3 shows all analyzed samples. Pigments (AMF18-26) from a local shop were analyzed because it was thought to have been used by Papaloukas, as this was a traditional shop since the days of Papaloukas, forgotten in some

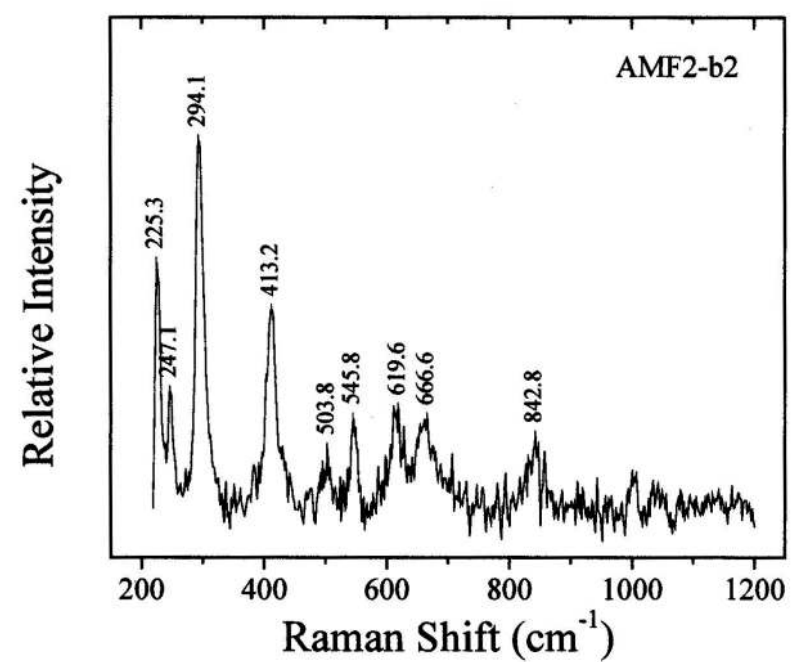

Figure 5: Amfissa Cathedral, womens gallery, sample AMF2 showing two painted layers. Here Raman spectrum of lower yellow layer (greater than 600 micrometer), reveals chromium yellow and yellow ochre.

Figure 5: Cathédrale d'Amfissa, galerie des femmes, échantillon AMF2 montrant 2 couches peintes. Ici le spectre Raman de la couche jaune inférieure (dépassant 600 micromètres) révèle du jaune chromé et de l'ocre jaune.

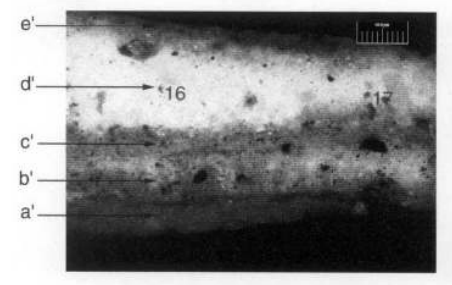

A

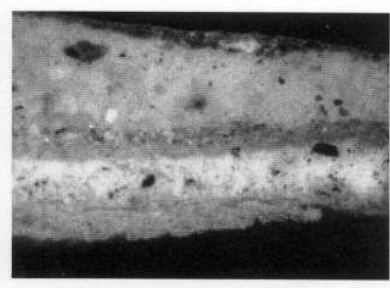

B
Figure 6: Photos with optical microscope for AMF13 ( $\triangle \Delta 3)$, plaster with colour from the window, women gallery, right aisle, $3^{\text {rd }}$ apse with five layers. The (a) left, is taken with white light and the (b) right, by UV light.

Figure 6: Photos au microscope optique sur AMF13, platre avec couleur provenant de la fenêtre, galerie des femmes, aile droite, $3^{e}$ abside avec 5 couches. La photo (a) à gauche est prise en lumière blanche et celle (b) de droite en lumière UV. 


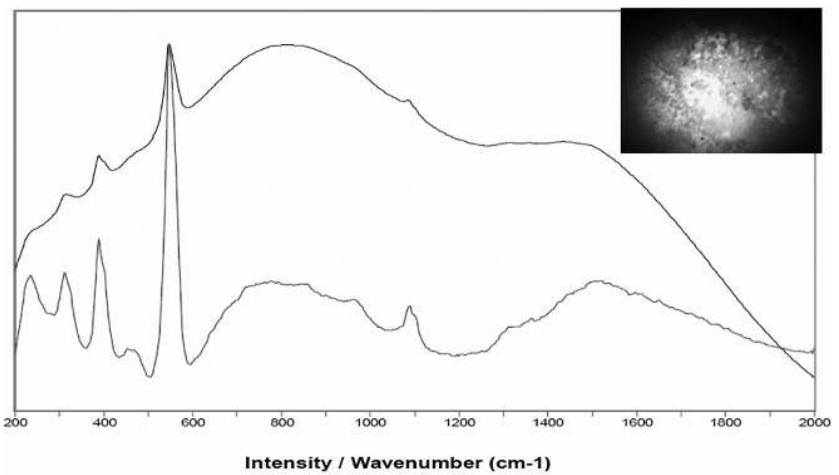

Figure 7: RAMAN spectrum (intensity/wavelength) of AMF13 layer $\mathrm{b}$ (the second amongst five layers) red mineral taken by ExamineR. The Blue spot is Ultramarine, taken from layer b, point 5 (layer thickness $90-100 \mu \mathrm{m}$ ). The two pigments identified on the basis of two spectra (see Fig. 6 and 9). Blue line (upper) includes fluorescence and red line (lower) is baseline corrected.

Figure 7 : Spectre Raman (intensité / longueur d'onde) de AMF13 couche $b$ (la seconde parmi les 5 couches), minéral rouge pris par ExamineR. Le point bleu est l'ultramarine, pris de la couche b, point 5 (épaisseur

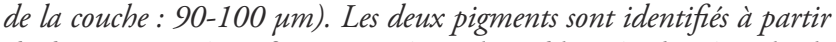
de deux spectres (voir figure 6 et 9). La ligne bleue (en haut) inclut la fluorescence et la ligne rouge (en bas) est la ligne de base corrigée.

old boxes thought to be as old as 70 years. None were used by Papaloukas.

9) Gas chromatography was employed to identify tempera (egg binder) and animal glue. Principal component (PCA) cluster analysis of the GC-MS samples was applied to identify binding media in comparison with available data bank. PCA employed the biplot of the first two component scores (see, Mantzourani \& Liritzis, 2006; Baxter, 1994). Animal glue was found, casein and egg, as binding substance in the preparation of grounds and in painted layers. In particular, for AMF5, AMF6, AMF16 was the egg, for AMF8, AMF10 was animal glue, and AMF15 near the cluster of casein. (Table 4, Fig. 8). The high content of glue in black flaked sample AMF15 causes the sample shift outside the milk cluster. This sample was analyzed microbiologically and exogenous factors action e.g. bio-deterioration actions were detected $^{8}$. The ingredients and properties of this glue seem to have attracted microorganisms. No further explanation can be given at the moment for the relationship between high glue content and presence of microbes, and this is under further investigation The GC analysis provided the

8. Microbiological analysis of three samples (AMF27, 30, 31) has detected, one bacterial species, one fungal species with dark mycelium and one species of Aspergillus (kindly made by Dr Alexander Boronin, Pushchino State University, Russia). amino acid contents for each of these samples as well as a histogram of percentage contents of amino acids.

\section{Conclusions}

The application of archaeometrical techniques increased understanding of the artist materials and working methods, thereby enhancing conservationist' ability to preserve these paintings. All the above methods of analysis complement each other, reinforce reliability, and clarify the technique of execution of such an important work of art with minute or non-destructive sampling.

The painter did not follow the usual a secco practice, instead he combined several painting techniques (pigments mixed with lime, tempera and oil) to open up new area of creative possibilities and mastered the natural characteristics of the pigments by the quality of his brushstrokes and the particular medium's degree of gloss.

The artist utilized unconventional materials to achieve desired visual and textural effects. However, his experimental techniques and low quality materials had a negative effect on the long term stability of his mural paintings, and pose major problems to conservators. It is indispensable the need to establish new conservation techniques to remove previous conservation materials and apply appropriate materials to stabilize the painting surface.

\section{Acknowledgements}

The authors wish to warmly thank late Mrs Mina Papalouka and Mrs Mary Michailidou for their encouragement of this project, the Amfissa Town Municipality and the Mayor of Amfissa for their aid and financial support. We are grateful to Mr Vassilios Theoharakis, Mr Ioannis Moscholios, the Cultural Foundation of the Alpha Bank, Greece, and the Silver and Baryte Ores Mining Co. S. A, for financial support. We extend our thanks to Mrs Ioanna Konstandinou painter, paper conservator for her advice and comments and Mr. Alexandros Polychroniadis for continuing support.

We appreciate Mrs Sibyle Nerger, Prof. Luigi Dei , David Park, Dr. Marcel Stefanaggi for their in situ comments and suggestions, and the Greek Ministry of Culture, Directorate of Conservation of Ancient and Contemporary Monuments, for granting permission to sampling.

Thanks to Mr Elias Magafas for technical assistant and the editor of FOKIS newspaper for permitting access to archives. 


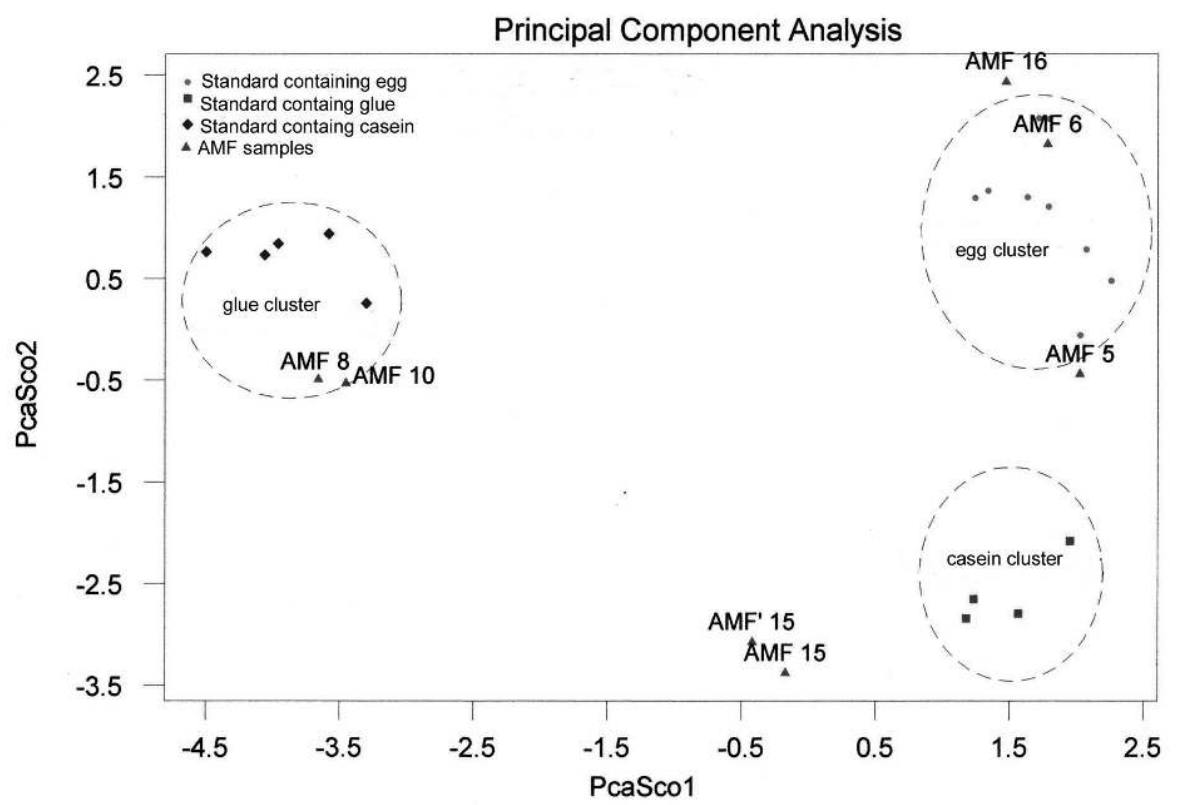

Figure 8: Principal Component analysis of six (6) samples analyzed by gas chromatographymass spectrometry, shown binding media (egg, animal glue, other near casein).

Figure 8: L'analyse en composante principale de 6 échantillons analysés par spectrométrie de masse en phase gazeuse, montre le liant. (ouf, colle animale, autre proche de la caséine).

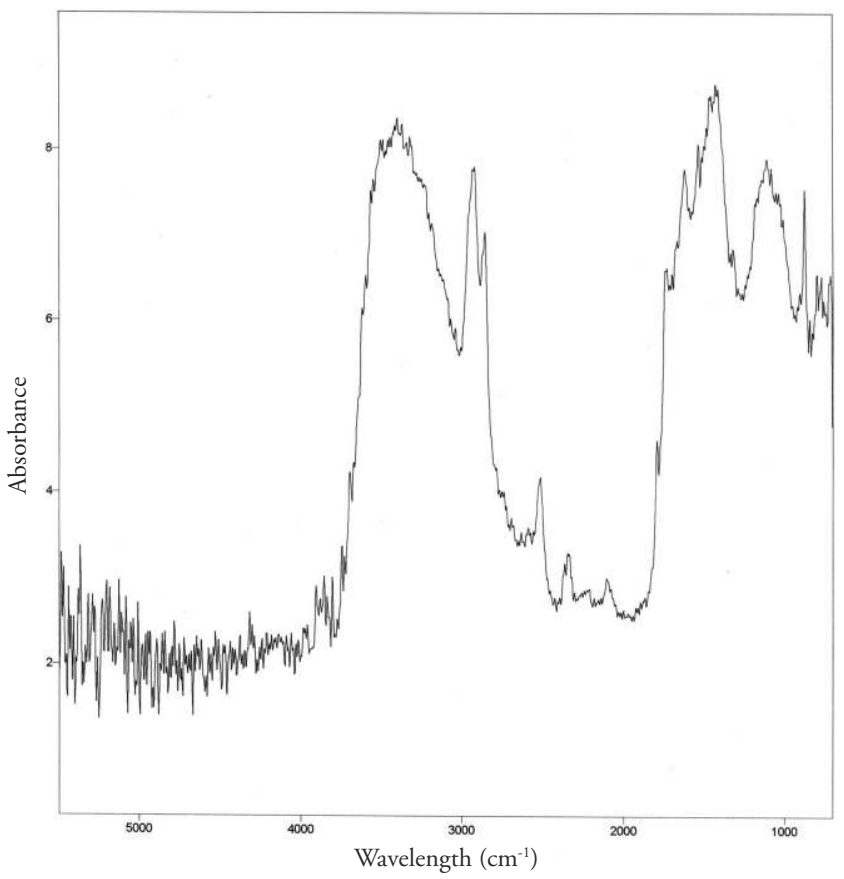

Figure 9: AMF13. Infrared photoacoustic spectrum showing absorbance values for pigments reported in Tables 2 and 3 .

Figure 9: AMF 13. Spectre photo-acoustique infrarouge montrant les valeurs d'absorption pour les pigments des tableaux 2 et 3.

\section{References}

Agnoli, F., Calliari, I. and Mazzocchin, G. A. 2007. Use of different spectroscopic techniques in the analysis of Roman wall paintings. Annali di Chimica, vol. 97, issue 1-2, p. 1-7.

Baumann, E., Zehnder, K., and RüEgG, T., 1998. Le chauffage des églises. Les difficultés de la recherche d'un équilibre entre les exigences de confort et les risques de dommages - l'exemple de la cathédrale de Coire. IAS Bulletin technique de la Suisse romande, 21, p. 342-349.

BAXTER, M. J, 1994. Exploratory multivariate analysis in archaeology. Edinburgh University Press.

BINDER, C., 1997. A technical study of the paintings in the choir of the Magdalenenkirche in Judenburg, Austria, Courtauld Institute of Art, London.

Bower, N. W., Stulik, D. C., and Doehne, E., 1994. A critical evaluation of the environmental scanning electron microscope for the analysis of paint fragments in art conservation." Fresenius' Journal of Analytical Chemistry 348, p. 402-410.

Cameron, M. A. S., Jones, R. E. and Fillipakis, S. E., 1977. Analyses of Fresco samples from Knossos. The Annals of the British School of Archaeology in Athens, 72, p. 123-184.

Calamiotou, M., Siganidou, M. and Fillipakis, S. E., 1983. X-ray analysis of pigments from Pella, Greece. Studies in Conservation, 28, p. 117-121. 
Capitano-Vallvey, L. F., Manzano, E. and Florez, M. V. J., 1994. A study of the materials in the mural paintings at the Corral del Carbon' in Granada, Spain. Studies in Conservation, 39, p. 87-99.

Church, A. H., 1915. The chemistry of paints and paintings, 4rth edition, Seeley and Co., London.

Cennini, C., 1933. Il libro dell arte. Firenze 1859, p. 94. The Craftman's Handbook. Translated by D.V.Thompson, Dover. (a $14^{\text {th }} \mathrm{c}$ book)

Clark, R. J. H. 2007. The scientific investigations of artwork and archaeological artefacts : Raman microscopy as a structural, analytical and forensic tool. Applied Physics A: Materials Science \& Processing, Vol.89, No.4, p. 833-840.

Coupry, C. and Lautie, 2001. A, Etude de la surface d'œuvres d'art par spectrometrie Raman, La Revue de Metallurgie, p. $789-793$.

Cotte, M., Checroun, E., Susini, J., and Walter, P., 2007. Microanalytical study of interactions between oil and lead compounds in paintings. Applied Physics A: Materials Science \& Processing, Vol. 89, no. 4, p. 841-848.

Doerner, M., 1984. The Materials of the artist and their use in painting. A Harvest book, Harcourt Brace \& Co.

Doenne, E. and Stulik, D. C., 1989. Applications of the Environmental Scanning Electron Microscope (E-SEM) to Conservation Science. Scanning Microscopy 4, no. 2, p. 275-286.

Eastlake, C. L., 1967. Materials for a history of oil painting, 2 vols, 1847 and 1869. Longman, London, Reprinted by Dover Publications, New York (1967).

Ferretti, M., 1993. Scientific investigations of works of art. ICCROM, $81 \mathrm{p}$.

Fillipakis, S. E., Perdikatsis, B. and Paradelis, T., 1976. An analysis of Bleu Pigment from Greek bronze Age, Studies in Conservation, 21, p. 143-153.

Fillipakis, S. E., Perdikatsis, B. and Assimenos, K., 1979. X-ray Analysis of Pigments from Vergina Greece, (second Tomb), Studies in Conservation, 24, p. 54-58.

Gettens, R. J., and Stout, G., 1966. Painting materials. A short Encyclopaedia. Dover publications, N.Y.

GowING, R., 1999. Digital insolation measurement: calibration of CCD camera recordings of reflected light intensity to produce values of incident lux exposure on wall paintings, In Proceedings of the 6th International Conference on "Non-destructive Testing and Microanalysis for the Diagnostics and Conservation of the Cultural and Environmental Heritage, I, Rome, p.283-296.

Grattan, D. W. (ed.) 1993. Saving the twentieth century: the conservation of modern materials. Conference Proceedings, Ottawa, Canada, 15-20 Sept. 1991. Ottawa, CCI, 440 p

GuINEAU, R., 1989. Non-destructive analysis of organic pigments and dyes using Raman microprobe, microfluorometer or absorption microspectrophotometer. Studies in Conservation, 34, p.38-44.
Goodall, R. A., Hall, J., Veil, R., Edwards, H. G. M. and Fredericks, P. M., 2004. Raman microscopic investigation of paint samples from buildings at Copan, Honduras, ICORS, Proceedings of the XIX International Conference on Raman Spectroscopy, p. 174-175.

KaKouli, I., 2002. Late the Classical and Hellenistic painting techniques and materials: a review of the technical literature, Reviews in Conservation, No 3, p. 56-67.

Kitson, F. G., McEwan, C. N. and Larsen, B., 1999. Gas chromatography and mass spectrometry, Academic Press Ltd, London.

Laurie, A. P., 1910a. Greek and Roman Methods of Painting, Cambridge University Press.

Laurie, A. P., 1910b. Materials of the 'Painters' Craft, T.N.Foulis, London and Edinburgh.

LEONA, M. and WinTER, J., 2001. Fiber optics reflectance spectroscopy: A unique tool for the investigation of Japanese paintings. Studies in Conservation. 46, p. 153-162.

Learner, T., Schilling, M. and La Rie, R. de, 2002. Modern paints: a new collaborative research project. The Getty Conservation Institute Newsletter 17.3, p. 18-20.

Liritzis, I., Drakonaki, T., Vafiadou, A., Sampson, A. and BoutsiKa, T., 2002. Destructive and non-destructive analysis of ceramics, artifacts and sediments of Neolithic Ftelia (Mykonos) by portable EDXRF spectrometer: First results, In Sampson. A (ed.), The Neolithic Settlement at Ftelia, Mykonos. University of the Aegean, Dept. of Mediterranean Studies, (Project GAIA, Interreg II), Rhodes, Greece, p. 251-271.

Liritzis, I., Katsaros, T., Thompson, T., Carron, K. and Cox, R., 2007. Identification and characterization of Greek artifacts with the Rockhound. Abstract ID 131747, Geol. Soc. America, Denver Annual Meeting, 28-31-Oct.

LiRITZIs, I., 2007. Assessment of Aegean obsidian sources by a portable ED-XRF analyser. In Proceedings of $4^{\text {th }}$ Hellenic Society Symposium, BAR International Series (Facorellis. G Zacharias, $\mathrm{N}$, Polikreti. K and Bakoulis. T, editors) (in press)

Liritzis, I., Katsaros, T., Stevenson, C. M. and Papageorgiou, I., 2008a. Theophrastus of Eressus treatise on stones: a new reference data bank of pigment characterization by infrared photoacoustic spectroscopy (in preparation).

Liritzis I., Polychroniadou, E., and Perdikatsis, V., 2008 b. Further spectroscopic investigations (XRD, SEM) of Amfissa Cathedral wall paintings (in preparation)

Low, M. J. D., and BAER, N. S., 1977. Application of infrared Fourier transform spectroscopy to problems in conservation. 1. General principles. Studies in Conservation, 22, p.116-128.

LORusso, S. and SCHIPPA, B. 2001. Le metodologie scientifiche per lo studio dei beni culturali. Diagnosi e valutazione tecnico-economica. 1st ed. Brossura, 320 p. (EAN: 9788837112592).

LuCAS, A, and Harris, J. R., 1962. Ancient Egyptian materials and industries, 4th edition, by J. Harris, London. 
Mantzourani, E. and Liritzis, I., 2006. Chemical analysis of pottery samples from Late Neolithic Kantou- Kouphovounos and Sotira- Tepes, Report of the Dept. of Antiquities, Cyprus, p. 63-76.

Mantler, M., and Schreiner, M., 2001. X-ray analysis of art and archaeology. In Liritzis. I (ed.), J. Radioanalytical \& Nucl. Chem., Vol. 247, no. 3, p. 635-644.

McClelland, J., Jones, R. W., Luo, S. and Seavenson, L. 1993. A practical guide to FTIR Photoacoustic Spectroscop'. In Practical Sampling Techniques for Infrared Analysis. Edited by P. B. Coleman. CRC Press, Boca Raton, Florida, Chapter 5.

Merrifield, M. P., 1849. Original Treatises Dating from the XIIth to XVIIIth Centuries on the Arts of paintings, 2 vols, J. Murray, London, Rerpinted by Dover Publications, New York.

Mora, P., Mora, L., and Philippot, P., 1984. Conservation of wall paintings, London.

Mills, J. S. and White, R., 1994. The organic chemistry of museum objects, 2nd Edition, Butterworth-Heinemann, London.,

Mills, J. S. and White, R., 1977. Natural resins in art and archaeology, their sources chemistry and identification, Studies in Conservation, 22, p.12-31.

Newman, S., Stolper, E. and Epstein, S., 1986. Measurement of water in rhyolitic glasses: Calibration of an infrared spectroscopic technique. American Mineralogist 71, p. 1527-1541.

Papageorgiou, I. and Liritzis, I., 2007. Multivariate mixture of normals with unknown number of components. An application to cluster Neolithic ceramics from Aegean and Asia Minor. Archaeometry, 49, 4, p. 795-813.

Puiny, Natural History (35th Book), The Loeb Classical Library (1958-1966), W. Heinemann Ltd, Cambridge MA.

ReED, H., 1966. Dictionary of Art and Artists, Thames and Hudson, London.
Schwan, E., 1998. Secular wall paintings in Normandy: condition and conservation priorities' (published as 'Les peintures murales de Sainte-Gauburge', Courtauld Institute of Art, London. In Art de Basse-Normandie, 116, p. 35-37.

Schilling M., Lake S., Steele E. and Lomax S. Q., 2002. Modern science and contemporary paintings: preserving an evolving legacy. The Getty Conservation Institute Newsletter 17.3, p. 4-10.

SPITERIS, T., 1982. Masters of the Greek painting of the 19th-20th century. Kastaniotis Press, Athens (in Greek).

Lambraki-Plaka, M., 2006. Spyros Papaloukas. Pinakotheke of New Hellenism. Hellenic Grammata, Athens. (In Greek).

Stevenson, C., Liritzis, I., Diakostamatiou, M., and Novak, S. 2002. Investigations towards the hydration dating of Aegean obsidian, Mediterranean Archaeology \& Archaeometry, 2, (1), p.93-109.

Hawthorne, J. G. and Smith, C. S., (translators) 1979. Theophilus, An Essay upon various arts, 1963, University of Chicago Press reprinted, Dover Publications, New York.

WALlert, A., 1995. Unusual pigments on a Greek marble basin, Studies in Conservation 40, p.177-188.

Welcomme, E., Walter, P., Bleuet, P., Hodean, J.-L., Dooryhee, E., Martinetto, P. and Menu, M., 2007. Classification of lead white pigments using synchrotron radiation micro X-ray diffraction. Applied Physics A: Matrerials Science \& Processing, Vol. 89, no. 4, p. 825-832.

White, R., 1981. A review, with illustrations, of methods applicable to the analysis of resin / oil varnish mixtures', ICOM Committee for Conservation Report 81/16/2, 6th Triennial Meeting, Ottawa.

White, R., 1978. Application of gas-chromatography to the identification of waxes, Studies in Conservation, 23, p.57-68. 
Table 1: Non-destructive analysis for pigment identification of colours on two pieces of anthivolo, by Raman and EDXRF methods. Note that EDXRF gives only chemical element concentration, while Raman spectroscopy gives information about the structure.

Tableau 1: Analyse non destructive pour l'identification de couleur de pigments sur deux pièces d'anthivolo, par les méthodes Raman et EDXRF. Notons que l'EDXRF donne uniquement les concentrations chimiques élémentaires, tandis que la spectroscopie Raman donne des informations sur la structure.

\begin{tabular}{|l|l|l|l|}
\hline $\begin{array}{l}\text { ANTHIVOLO } \\
\text { SAMPLE REF }\end{array}$ & COLOUR & PIGMENT & METHOD \\
\hline $\begin{array}{l}\text { AMFA-1 } \\
(26 \times 56,5-59 \mathrm{~cm})\end{array}$ & Yellow & Lead chromate sulfate & $\begin{array}{l}\text { Raman, } \\
\text { EDXRF }\end{array}$ \\
\hline & $\begin{array}{l}\text { Black } \\
\text { Black stain }\end{array}$ & $\begin{array}{l}\text { Carbon } \\
\text { Contains iron (sienna) })\end{array}$ & $\begin{array}{l}\text { Raman } \\
\text { EDXRF }\end{array}$ \\
\hline & Red stain & $\begin{array}{l}\text { Iron Oxide (sienna) } \\
\text { Iron Oxide }+ \text { Titanium } \\
\text { dioxide white }\left(\mathrm{TiO}_{2}\right)\end{array}$ & Raman \\
\hline & EDXRF \\
\hline & Red & Ultramarine & Raman \\
\hline $\begin{array}{l}\text { AMFA-2 } \\
(18 \mathrm{x} 85 \mathrm{~cm})\end{array}$ & Red & Iron Oxide $($ sienna) $)$ & Raman \\
\hline & Blue & Ultramarine & Raman \\
\hline & Dark blue & Prussian blue & Raman \\
\hline & Black & Carbon & Raman \\
\hline & White & TiO & Raman \\
\hline & Yellow & Lead chromate sulfate & Raman \\
\hline
\end{tabular}

Table 2: Raman measurements for pigment identification of crosssectioned samples AMF29, AMF13 and AMF2, derived from women gallery, right aisle $3^{\text {rd }}$ apse and prepared in a resin matrix (see, Fig. 6). Lettering (A, B, ...) corresponds to analysed sandwiched layers, and the numbers refer to the particular point within the layer with obvious colour.(AMF: AMFISSA + numbering of sampling, $\Gamma \Delta 3$ : $\Gamma$ for women gallery (gynaeceum), $\Delta$ for right aisle, 3 for $3^{\text {rd }}$ apse). Spot colours analysed include red, green, black, yellow, blue, orange, white. [NOTE for the unknowns, underlined is the higher relative intensity. Raman Wavelengths $\left(\mathrm{cm}^{-1}\right){ }^{*}$ A4: $233.8,311.4, \underline{675.2}$; ** A7 (rather some organic substance) $292.2,332.4,510.7,546.9,644.7, \underline{686.3}, 707.7,741.2$, $\underline{777.4}, 819,958.4, \underline{979.8}, \underline{1083}, \underline{1213}, \underline{1281.4}, \underline{1377.7}, 1392.7$, $\underline{1444.3}, 1481.1, \underline{1537.4}, 1596.4,2822,2873.8,3074.9$. $^{* * *}$ D6: 414.2, 493.3, 546.9, 622, 671.6, 1008, 1099.1, 1306.9, 3404, 3490].

Tableau 2: Mesures Raman pour l'identification de pigments sur des sections des échantillons AMF29, AMF13 et AMF2 de la galerie des femmes, aile droite $3^{e}$ abside, et préparés dans une matrice de résine (voir fig. 6). Les lettres ( $A, B \ldots$ ) correspondent aux couches analysées, et les numéros font référence aux points particuliers dans la couche ayant une couleur évidente (AMF: AMFISSA + numérotation de l'échantillonnage, $\Gamma \Delta 3: \Gamma$ pour galerie des fermmes (gynécée), $\triangle$ pour aile droite, 3 pour $3^{e}$ abside). Les point colorés analysés incluent le rouge, le vert, le noir, le jaune, le bleu, l'orange, le blanc. [note pour les indéterminés: les longueurs d'onde Raman des intensités relatives les plus élevées sont soulignées: * A4: 233,8, 311,4, 675,2; ** A7 (plutôt une substance organique) 292,2, 332,4, 510,7, 546,9, $644,7,686,3,707,7,741,2,777,4,819,958,4,979,8, \underline{1083}$, 1213, 1281,4, 1377.7, 1392.7, 1444,3, 1481,1, 1537,4, 1596,4, 2822, 2873,8, 3074,9. *** D6: 414,2, 493.3, 546,9, 622, 671,6, $\underline{1008}, \underline{1099,1}, 1306,9,3404,3490]$.

\begin{tabular}{|c|c|c|c|c|}
\hline Sample ref. & Layer & $\begin{array}{l}\text { Analysed } \\
\text { Point }\end{array}$ & Colour & Pigment \\
\hline \multirow{13}{*}{$\begin{array}{l}\text { AMF29 } \\
\Gamma \Delta 3, \text { lower part }\end{array}$} & A & 1 & Red & Haematite \\
\hline & & 2 & Yellow & $\begin{array}{l}\text { Red \& Yellow } \\
\text { Ochre }\end{array}$ \\
\hline & & 3 & Red & $\begin{array}{l}\text { Red\&Yellow } \\
\text { ochre } \& \mathrm{SiO}_{2}\end{array}$ \\
\hline & & 4 & Black & Uknown* \\
\hline & & 6 & Black & Carbon \\
\hline & & 7 & Green & $\begin{array}{l}\text { Unknown } \\
\text { Organic }\end{array}$ \\
\hline & & 8 & Blue & Ultramarine \\
\hline & $\mathrm{B}$ & 1 & Blue & Ultramarine \\
\hline & & 2 & Blue & $\begin{array}{l}\text { Ultramarine } \& \\
\text { Prussian blue }\end{array}$ \\
\hline & $\mathrm{C}$ & 7 & Blue & Ultramarine \\
\hline & $\mathrm{D}$ & 3 & Red & $\begin{array}{l}\text { Red ochre \& } \\
\text { Prussian Blue }\end{array}$ \\
\hline & & 4 & Blue & Ultramarine \\
\hline & & 5 & Blue & $\begin{array}{l}\text { Ultramarine } \& \\
\text { Prussian blue }\end{array}$ \\
\hline
\end{tabular}




\begin{tabular}{|c|c|c|c|c|}
\hline & & 6 & Green & $\begin{array}{l}\text { Unknown } \\
\text { Organic }{ }^{* * *}\end{array}$ \\
\hline & E & 1 & Blue & $\begin{array}{l}\text { Ultramarine \& } \\
\text { Gypsum }\end{array}$ \\
\hline & & 2 & Blue & $\begin{array}{l}\text { Ultramarine \& } \\
\text { Gypsum }\end{array}$ \\
\hline & & 3 & Green & $\begin{array}{l}\text { Unknown } \\
\text { Organic as D6 }\end{array}$ \\
\hline & & 4 & Red & $\begin{array}{l}\text { Red ochre \& } \\
\text { Ultramarine }\end{array}$ \\
\hline & & 5 & Blue & $\begin{array}{l}\text { Ultramarine \& } \\
\text { Gypsum }\end{array}$ \\
\hline & & 6 & Blue & $\begin{array}{l}\text { Gypsum \& } \\
\text { Ultramarine }\end{array}$ \\
\hline \multirow{19}{*}{$\begin{array}{l}\text { AMF13, } \\
\Gamma \triangle 3 \text { plaster } \\
\text { (Mortar) with } \\
\text { colour from the } \\
\text { window in the } \\
\text { conch of the 3rd } \\
\text { apse }\end{array}$} & A & 1 & $\begin{array}{l}\text { Yellow } \\
\text { Orange }\end{array}$ & $\begin{array}{l}\text { Chrome yellow } \\
\text { Fluorite }\end{array}$ \\
\hline & & 2 & Yellow & Yellow ochre \\
\hline & & 3 & White & \begin{tabular}{|l|}
$\begin{array}{l}\text { Calcium } \\
\text { carbonate }\end{array}$ \\
\end{tabular} \\
\hline & $\begin{array}{l}\text { B, 90- } \\
100 \text { um }\end{array}$ & 4 & Red & Red ochre \\
\hline & & 5 & Blue & Ultramarine \\
\hline & & 6 & White & \\
\hline & & 7 & black & Carbon \\
\hline & $\begin{array}{l}\text { C, 60- } \\
70 \text { um }\end{array}$ & 8 & yellow & Chrome yellow \\
\hline & & 9 & red & \\
\hline & & 10 & blue & Ultramarine \\
\hline & & 11 & white & \\
\hline & & 12 & lacquer & \\
\hline & & 13 & yellow & \\
\hline & & 14 & black & Carbon \\
\hline & $\begin{array}{l}\mathrm{D}, 200 \\
\text { um }\end{array}$ & 15 & white & $\begin{array}{l}\text { Calcium } \\
\text { carbonate }\end{array}$ \\
\hline & & 16 & yellow & Chrome Yellow \\
\hline & & 17 & brown & Red ochre \\
\hline & & 18 & green & Prussian blue \\
\hline & $\begin{array}{l}\text { E, about } \\
30 \text { um }\end{array}$ & 19 & yellow & Yellow ochre \\
\hline \multirow{4}{*}{$\begin{array}{l}\text { AMF2 } \\
\text { Yellow } \\
\text { pigment flake. } \\
\text { Vault }\end{array}$} & $\begin{array}{l}\text { A, }>600 \\
\text { um }\end{array}$ & 1 & yellow & $\begin{array}{l}\text { Chrome yellow + } \\
\text { Yellow ochre }\end{array}$ \\
\hline & \begin{tabular}{|l} 
B, \\
about \\
50 um
\end{tabular} & 2 & red & Red ochre \\
\hline & & 3 & yellow & $\begin{array}{l}\text { Chrome Yellow } \\
\text { (FTIR: kaolinite) }\end{array}$ \\
\hline & & 4 & blue & Ultramarine \\
\hline
\end{tabular}

Table 3: Sample location, color, method used and pigment identification by different methods of colors on minute samples from various points of the wall painting (high barium contents as $\mathrm{BaCO} 3$ white are present rather for weight increase and thus higher cost). Portable EDXRF analyses refer to a non destructive manner right on a larger area on the surface mural painting. Chemical elements are reported which reflect known compounds. In contrast to the tiny samples detached and analyzed by Raman and FTIR. The compounds here are recognized from a data bank spectral library. Manganese and iron oxides (ochres) and minion were used in ancient times.

Tableau 3 : Localisation de l'échantillon, couleur, méthode utilisée et identification du pigment par différentes méthodes de couleurs sur de minuscules échantillons provenant de différents endroits de la peinture murale (de fortes teneurs en barium blanc $\mathrm{BaCO}_{3}$ sont présentes plutôt pour un accroissement de poids, et ainsi pour un coût plus élevé). Les analyses EDXRF in situ se réferent à une approche non destructive sur une plus grande surface de la peinture murale. Les éléments chimiques reflètent des composés connus. Par contraste avec les échantillons minuscules détachés et analysés par Raman et FTIR. Les composés ici sont reconnus à partir d'une banque de données spectrale. Les oxydes de manganèse et de fer (ocres) et leurs dérivés étaient utilisés dans les temps anciens.

\begin{tabular}{|c|c|c|c|c|}
\hline $\begin{array}{l}\text { Sample } \\
\text { ref. }\end{array}$ & Description & Color & Pigment & Method \\
\hline AMF2 & $\begin{array}{l}\Gamma \Delta 3, \text { women } \\
\text { gallery, right aisle } 3^{\text {rd }} \\
\text { apse, yellow } \\
\text { flaked pigment }\end{array}$ & Yellow & $\begin{array}{l}\text { In } 4 \text { successive } \\
\text { painted layers: } \\
\text { Chrome yellow+ } \\
\text { Yellow ochre+ } \\
\text { Ultramarine+ } \\
\text { Red ochre } \\
\text { (yellow } \\
\text { ochre=kaolinite by } \\
\text { FTIR) } \\
\text { High content: } \\
\text { Pb and Fe } \\
\text { (mainly yellow from } \\
\text { similar pigments as } \\
\text { above) }\end{array}$ & EDXRF \\
\hline AMF3 & $\begin{array}{l}\Gamma \Delta 2 \text {, women gallery } \\
\text { Right aisle, } 2 \text { nd apse. } \\
\text { Red } \\
\text { Flaked pigment }\end{array}$ & Red & $\begin{array}{l}\text { Iron Oxides } \\
+\mathrm{Ca}+\mathrm{Sr} \\
\text { Red ochre }\end{array}$ & EDXRF \\
\hline AMF4 & Pulpit, red decoration & Red & $\begin{array}{l}\text { High Fe, Ca, } \\
\text { Sr, Ba. } \\
\text { Red ochre }\end{array}$ & EDXRF \\
\hline AMF5 & $\begin{array}{l}\text { Left aisle } \\
\text { Internal side } \\
\text { of column }\end{array}$ & Blue & $\begin{array}{l}\text { High } \mathrm{Fe}, \\
\mathrm{Ba}, \mathrm{CaCO}_{3} \text {, } \\
\mathrm{K}, \text { Prusian Blue }\end{array}$ & $\begin{array}{l}\text { EDXRF, } \\
\text { FTIR, IRPAS, }\end{array}$ \\
\hline AMF12 & $\begin{array}{l}\Gamma \Delta 3 \text { Women } \\
\text { gallery, right aisle, } 3^{\text {rd }} \\
\text { apse ) }\end{array}$ & Blue & $\begin{array}{l}\text { High } \mathrm{Fe} \\
\text { and } \mathrm{CaCO}_{3} \text {. } \\
\text { Red ochre }\end{array}$ & EDXRF \\
\hline AMF13 & $\begin{array}{l}\Gamma \Delta 3, \text { Women } \\
\text { gallery, right } \\
\text { aisle, window } \\
\text { in the coche of the } \\
3 \text { rd apse }\end{array}$ & 5 layers & $\begin{array}{l}\text { Chrome yellow, } \\
\text { Red ochre, } \\
\text { Ultramarine, } \\
\text { Carbon, } \\
\text { etc (details in } \\
\text { Table 2) }\end{array}$ & $\begin{array}{l}\text { Raman, } \\
\text { FTIR, IRPAS }\end{array}$ \\
\hline
\end{tabular}

ArCheoSCIEnCES, revue d'archéométrie, 31, 2007, p. 97-112 


\begin{tabular}{|c|c|c|c|c|}
\hline AMF14 & $\begin{array}{l}\text { Pulpit } \\
\text { Part of surface } \\
\text { Flaky pigment on } \\
\text { paper with lettering }\end{array}$ & Yellow & $\begin{array}{l}\text { Yellow of Pb-Sn } \\
+\mathrm{PbO}, \mathrm{K}, \mathrm{Fe} \\
\text { (a surprising result } \\
\text { which can not at } \\
\text { present be justified) }\end{array}$ & EDXRF \\
\hline AMF15 & $\begin{array}{l}\text { Pulpit } \\
\text { Paper with letters }\end{array}$ & Black & & FTIR, IRPAS \\
\hline AMF16 & $\begin{array}{l}\Gamma \Delta 2, \text { women } \\
\text { gallery right aisle, } \\
\text { 2nd apse. }\end{array}$ & Brownish & Red ochre & Raman, \\
\hline AMF17 & $\begin{array}{l}\Gamma \Delta 3, \text { women } \\
\text { gallery right aisle, } \\
\text { 3rd apse red from } \\
\text { the vault }\end{array}$ & Red & $\begin{array}{l}\text { Red lacquer + } \\
\text { Red ochre. } \\
\\
\text { Iron oxides + } \\
\mathrm{MnO}_{2}+ \\
\text { Clay. Red ochre }^{+}\end{array}$ & $\begin{array}{l}\text { Raman } \\
\text { EDXRF }\end{array}$ \\
\hline $\begin{array}{l}\text { AMF18- } \\
\text { AMF26 }\end{array}$ & Local shop & \begin{tabular}{|l} 
Various \\
colours \\
(modern \\
pigments)
\end{tabular} & $\begin{array}{l}\text { Gypsum, minium, } \\
\text { Oxides of } \\
\text { manganese } \\
\text { and iron, } \\
\text { high barium }\end{array}$ & EDXRF \\
\hline
\end{tabular}

Table 4: Gas chromatography-mass spectrometry (percentage of aminoacids present and comparison with a data bank via principal component analysis score plots) and FTIR and IR-PAS screening (spectra compared with data bank) for detection of organics of samples from various parts of the wall painting.

Tableau 4: Spectrométrie de masse en phase gazeuse (pourcentage d'acides aminés présents et comparaison avec la banque de données via un diagramme d'analyse en composantes principales), et filtrage FTIR et IR-PAS pour détection d'éléments organiques sur des échantillons de différentes parties du mur peint.

\begin{tabular}{|l|l|}
\hline SAMPLE REF. & BINDING MEDIA \\
\hline AMF-5, AMF-6, AMF-16 & $\begin{array}{l}\text { Egg (main stretching frequencies: 463, } \\
530,618,794,926,1009,1097,1359, \\
\left.1577,3325,3500,3587 \mathrm{~cm}^{-1}\right)\end{array}$ \\
\hline AMF-8, AMF10 & Animal glue \\
\hline AMF-15 & Near Casein cluster \\
\hline AMFA-1 (Anthivolo) & $\begin{array}{l}\text { Paper / oil, Absorbance : 897, 1061, 1161, } \\
1267,1317,1373,1427,1508,1653,2905, \\
\end{array}$ \\
& $3353 \mathrm{~cm}^{-1}$. \\
\hline
\end{tabular}

